\title{
819 ダム利水放流設備の副ゲート用空気弁の自励振動
}

\section{Self-Excited Vibration Tests of Air Supply Valve for Ring Follower Gate in Water Release Pipe System of Dam}

\author{
正 阿南 景子（足利工大）＼cjkstart正 石井 徳章（阪電通大）＼cjkstart巻幡 敏秋（元日立造船） \\ 正 奥 達也（前川製作所） \\ ○紺屋 佳宏 (阪電通大院) \\ 谷野 真吾 (阪電通大院卒) \\ 前川 知宽(阪電通大)
}

\begin{abstract}
Keiko ANAMI, Ashikaga Institute of Technology, 268-1 Omae-cho, Ashikaga, Tochigi 326-8558, Japan Noriaki ISHII, Osaka Electro-Communication University, 18-8 Hatsu-chou, Neyagawa, Osaka 572-8530, Japan Toshiaki MAKIHATA, Consultant, 4-20-4 Matsugaoka, Takatsuki, Osaka 569-1031, Japan Tatsuya OKU, Mayekawa MFG. Co., Ltd., 2000 Tatsuzawa, Moriya-city, Ibaraki 302-0118, Japan Shingo TANINO, Osaka Electro-Communication University Yoshihiro KONYA, Osaka Electro-Communication University Tomohiro MAEKAWA, Osaka Electro-Communication University
\end{abstract}

This paper presents the model test results of self-excited vibration of the air supply valve for the ring flower gate in the water release pipe system of dam. The water release pipe system has the main gate and the sub-gate. The sub-gate surely has air valve for inhalation of air. The intense self-excited vibration was occurred in the water release pipe system under practical use. The intense vibration occurred when the air valve was closed, while water was accumulated in the pipe system. Although it is thought that the water hammer generated in the upstream participated in this problem, the main reason is not clarified. In this study, the self excited vibration related to the actual problem was revealed, using the model of the water release pipe system and the air valve.

Key Words: Flow-Induced Vibration, Self- Excited Vibration, Dam, Pipe System, Ring Follower Gate, Air Valve

ダム放水管設備には主ゲートと副ゲートが設置され、副ゲ 一トの下流側には吸気のために必ず空気弁が設置される。空 気弁は長い空気管を介して副ゲート下流側につながっている。 その空気弁が放水設備の点検作業中に激しい自励振動を引起 こすという問題が 2003 年に発生した。主ゲートと副ゲートを 共に締め切った状態で主管と空気管に充水をしていたとき、 空気弁が閉まると同時に非常に激しい自励振動を引起した。 重大事故にもつながる恐れがあるので、自励振動現象の発生 原因を是非明らかにしておく必要がある。

そこで本研究では、初めての試みとして、実機と等価な放 水管設備・空気管・空気弁の小形モデルを製作し、それを用 いて振動実験を行った。その結果、空気弁の自励振動現象を 再現することができたので、その概要を報告与る。

小形モデルはトラブルが発生したダム放水管設備の約 $1 / 4$ スケールモデルである。図 1 に空気弁のイラストを示している。 事故が発生したダム放水管設備の空気管内径は $300 \mathrm{~mm}$ であっ たので、空気管の内径は $80 \mathrm{~mm}$ に設定している。半球状の空気 弁の直径は $150 \mathrm{~mm}$ である。空気弁はばね支持されているので、 それを代表させるために図 1 に示すような「てこ」を介したば ね支持系にしている。これによって空気弁の固有振動数を調整 できる。

自励振動には空気管内に発生する水撃波が密接に関係して いるものと考えられるので、その固有振動数を決める空気管の 長さを実機の $26 \mathrm{~m}$ よりも長い $80 \mathrm{~m}$ に設定した。これによって 水撃波を実機よりも低い周波数で観測できるようになる。主管 の直径は空気管の約 5 倍の大きさ $(1.4 \mathrm{~m})$ であり、水撃波を反射 する役割をしているものと考えられるので、実験装置では主管
を容量の大きな直径 $400 \mathrm{~mm}$ 密閉タンクで代表させた。 水槽内の水中ポンプによって送水された水が密閉タンク、空 気管を通って空気弁に達すると、浮力によって空気弁は上に押 上げられて閉まろうとする。そのときの振動現象を非接触型振 動計によって計測した。水中ポンプ回転数が 1440rpmに上がっ て空気管内の圧力が比較的早く上昇するとき、空気弁がもっと も激しく自励振動する現象が観測できた。空気管内に激しい水 撃波が発生していることも確認できた。

自励振動の振動数は $1.8 \mathrm{~Hz}$ であった。一方、水撃波の固有振 動数は $2.1 \mathrm{~Hz}$ であり、自励振動数によく一致した值であった。 したがって、空気管内に発生する自励振動の周波数は空気管内 の水撃波固有振動によって決められているといえる。

もし、水撃波固有振動が空気弁の水中固有振動数に一致すれ ば、きわめて激しい自励振動が発生するものと考えられる。

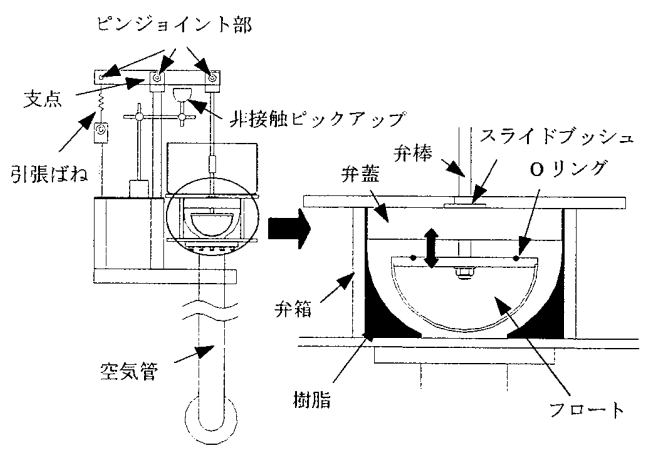

Figure A1: Schematic view of the air valve. 
1. 緒言

ダムには維持放流のための放水管設備が必ず併設される。 放水管設備は基本的に主ゲートと副ゲートから構成され、副 ゲート下流には給気目的のために必ず空気管と空気弁が設置 される。あるダムの放水管設備全体のレイアウトを図 1 に示 す。空気管の長さは $26 \mathrm{~m} ゙$ あり、その先端に空気弁が設置さ れている。

2003年、主ゲートと副ゲートを共に締め切った状態で放水 管に充水していたとき、空気弁が締め切り状態になると同時 に激しい自励振動を発生した (1)。水撃作用（Water Hammer） が関与してこのような激しい振動が発生したと考えられてい るが、未だその原因は明確に確認されていない。

そこで本研究では、空気管内で発生する水撃波の固有振動 数と空気弁の固有振動数が一致したために空気弁の自励振動 が発生したものと想定して実際と等価な放水管設備・空気 管・空気弁の小形モデルを製作し、動的不安定現象を再現す る実験を行った ${ }^{(2)-(4)}$ 。

\section{2. 実験モデル}

2.1 空気弁 実機の空気弁を図 2(a)に示す。弁体内部では 半球状のフロートが弁棒を介して圧縮ばねで吊り上げられて いる。フロートの外径は $150 \mathrm{~mm}$ である。内径 $300 \mathrm{~mm}$ の弁体 下部からフロート部分に水が上昇してくると浮力によってフ ロートは押し上げられ、空気が完全に抜出すのと同時にフロ 一トの上面が弁座に当たって水の噴出が止められることにな る。そのときの衝撃を緩和するために圧縮ばねの下方に空気 ダンパー室が設けられている。

空気弁を忠実に再現したモデルが図 2(b)である。フロート には直径 $150[\mathrm{~mm}]$ 、肉厚 $2.5[\mathrm{~mm}]$ のアクリル製半球を用いて いる。実機の約 1/4 スケールを大体の目安にしている。フロ 一ト上部には蓋が取付けられており、その外周部には止水用 O リングが設置されている。蓋の中央には弁棒が設置され、 スライドブッシュに挿入されているので、フロート全体がス ムーズに上下運動できるようになっている。弁棒の先端には 「てこ」を介してばねが取付けられている。ばねの取付け位 置を左右にスライドさせることによってフロートの固有振動 数を変化させることができる。

2.2 放流配管設備 図 1 に示した放流設備の小形モデルを 図 3 に示す。自励振動には空気管内に発生する水撃波が密接に 関係しているものと考えられ、さらに、主管の直径 $(1.4 \mathrm{~m})$ は空 気管の直径 $(300 \mathrm{~mm})$ よりも十分に大きいので主管は水撃波を反 射する役割を果たしているものと考えられる。そこで、小形放 流設備モデルでは、主管を容量の大きな密閉タンク(直径 400 $\mathrm{mm}$ 、高さ 400mm)で代表させている。その側壁に実機の空気 管(長さ $26 \mathrm{~m}$ )よりも長い $80 \mathrm{~m}$ の空気管(内径 $80 \mathrm{~mm}$ )を接続し、 その先端に空気弁を取付けている。空気弁の直前では空気管を 約 $2 \mathrm{~m}$ だけ鉛直に立上げている。その部分の様子を図 4 に示し ている。空気管を伝播する水撃波の密閉タンクでの反射率は約 90\%である。空気管は、水撃波を効率よく伝播できるように、 鋼管製にしている。内面には防錆のために硬質塩化ビニルラ イニング加工をしている。

この小形放流設備モデルによって実機と同じ程度の低い周 波数で水撃波と関係した振動現象を観測できるようになる。た だ、80mm の空気管は途中 5 箇所で曲げられた部分がある。こ れが水撃波の伝播にある程度影響するものと考えられる。

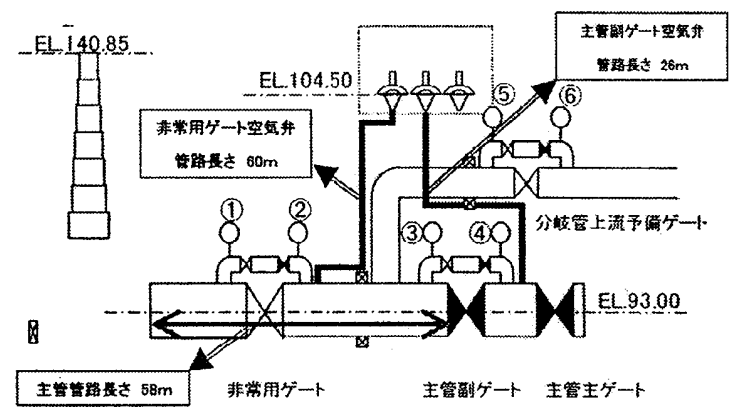

Figure. 1 ダム放水管設備概略図

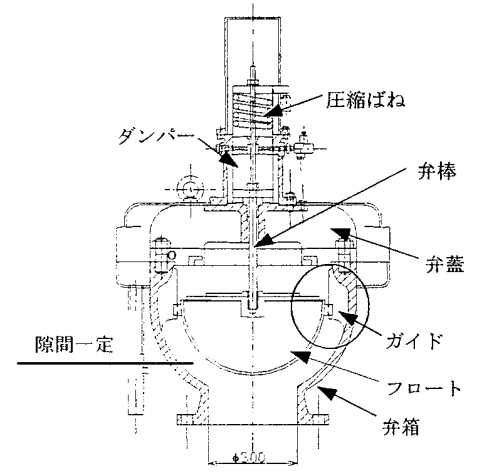

(a) 実機

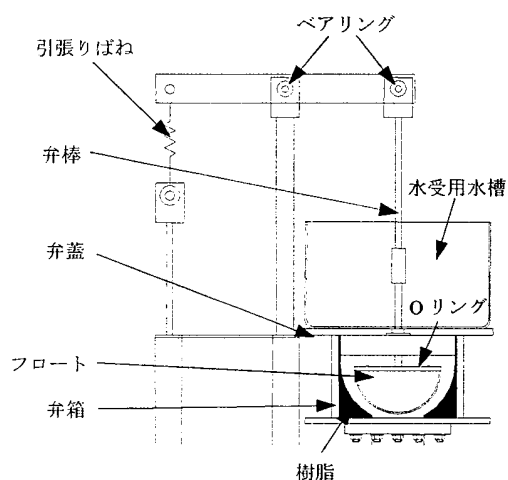

(b) 1/4 スケールモデル

Figure.2 空気弁

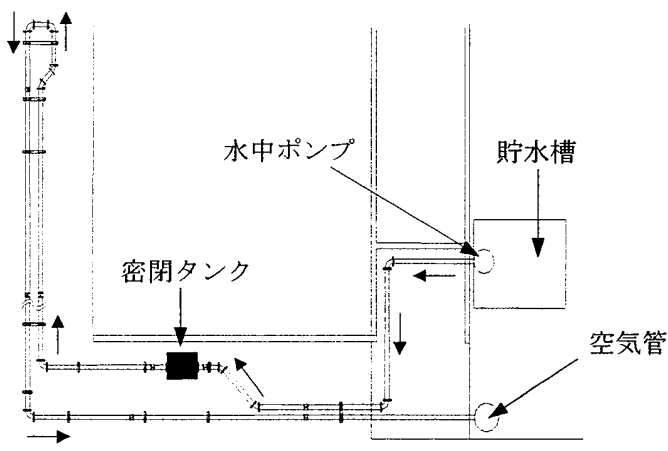

Figure.3 小形放流設備配管モデルの概略図 


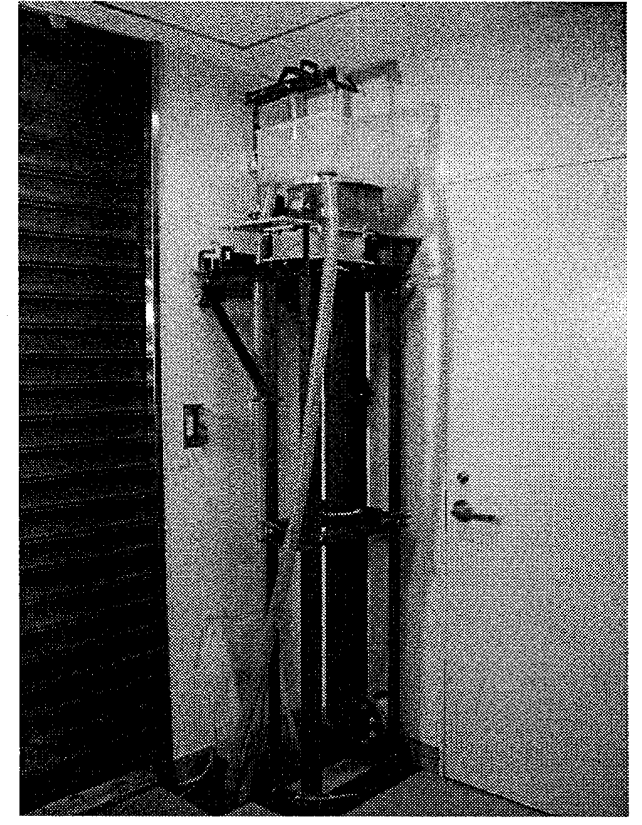

Figure.4 空気弁と立ち上がり空気管

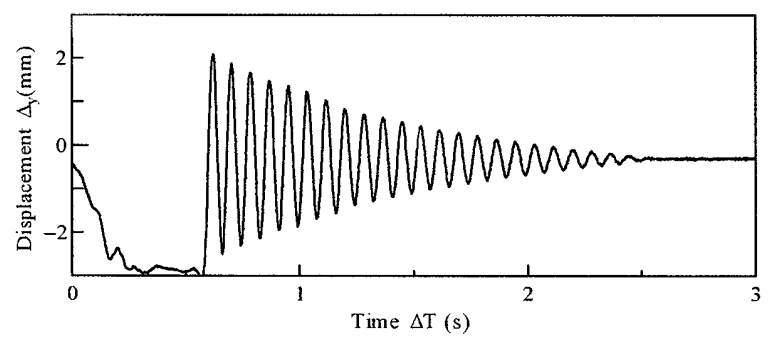

Figure.5 フロートの空中での減衰振動波形 $\left(\omega_{\mathrm{n}}=4.0 \mathrm{~Hz}\right)$

\section{3. 実験方法および実験結果}

図 3 に示しているように、水槽内に設置した水中ポンプで 密閉タンク、空気管、空気弁へと送水している。タンクと空気 管内部の空気を完全に除いた状態でフロートの振動現象を観 測した。実験では空気管内の圧力を高めるために水中ポンプの 回転数を上げた。本来ならば空気管内圧力を測定ず゙きである が、その圧力測定前に空気弁が水撃波の高圧に耐えられないで 破損したため、圧力測定ができていない。そこで、ここでは圧 カの目安として水中ポンプの回転数で実験データを整理して いる。

図 5 はフロートの空中での減衰振動波形を示している。固有 振動数は $4.0 \mathrm{~Hz}$ 、減衰比は 0.019 であった。この設定で小形放 流設備モデル内に送水し、フロートの振動を計測した。主要な 結果の一部を図 6 に示している。

水中ポンプ回転数がもつとも小さな $772 \mathrm{rpm}$ のとき、すなわ ち空気管内の圧力があまり大きくない状態のときに観測され た振動波形を(a)図に示している。図に示す $A$ 点でフロートが急 激に閉まり、その閉塞状態が約 $\Delta \mathrm{T}=0.27 \mathrm{~s}$ だけ持続している。そ の後、フロートは急に開いて減衰振動をしている。その振動数 は $2.71 \mathrm{~Hz}$ であった。減衰振動が収まった後、フロートは徐々 に上昇し、最後に急激に閉まっている。フロートの動きの基本 周期は $3.69 \mathrm{sec}$ であり、基本振動数はかなり低い $0.27 \mathrm{~Hz}$ であっ た。この振動波形の表す大切な点は、第 1 に、水の付加質量効

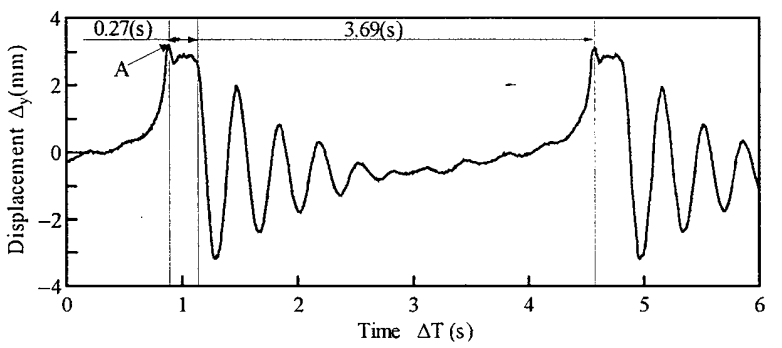

(a) 水中ポンプ回転数 $772[\mathrm{rpm}]$

（弁閉塞時閒 $0.27 \mathrm{~s}$; 減衰振動数 $2.71 \mathrm{~Hz}$; 基本振動数 $0.27 \mathrm{~Hz}$ )

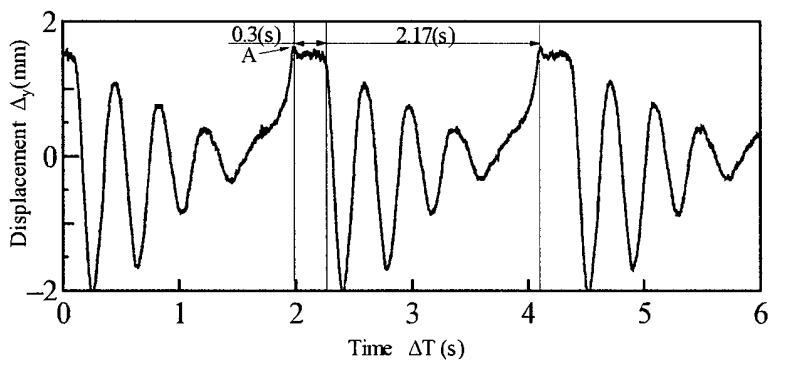

(b) 水中ポンプ回転数 $822[\mathrm{rpm}]$

（弁閉塞時間 $0.3 \mathrm{~s}$; 減衰振動数 $2.86 \mathrm{~Hz}$; 基本振動数 $0.48 \mathrm{~Hz}$ )

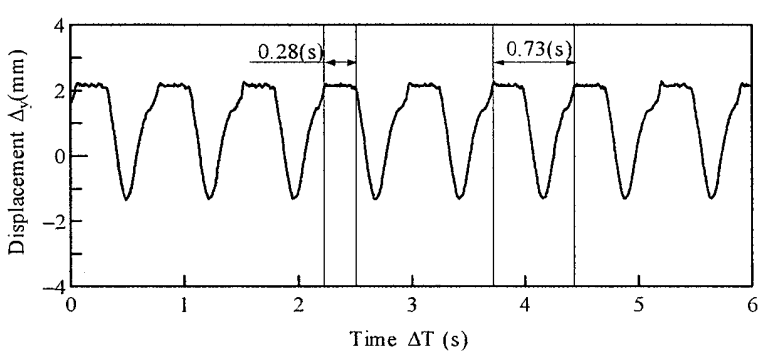

(c) 水中ポンプ回転数 $1050[\mathrm{rpm}]$ （弁閉塞時間 $0.28 \mathrm{~s}$; フロート基本振動数 $1.37 \mathrm{~Hz}$ )

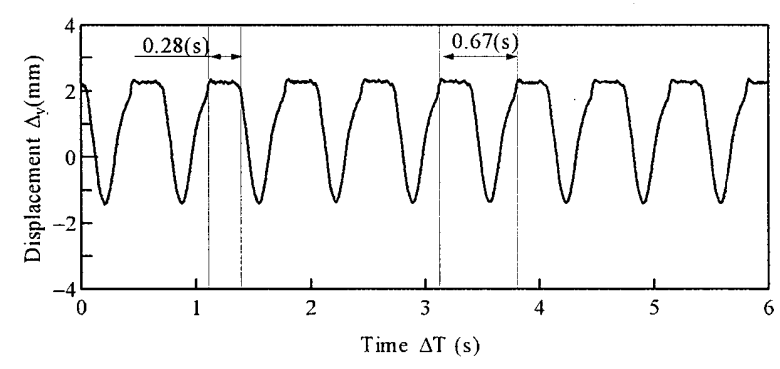

(d) 水中ポンプ回転数 $1095[\mathrm{rpm}$ （弁閉塞時間 $0.28 \mathrm{~s}$; フロート基本振動数 $1.49 \mathrm{~Hz}$ )

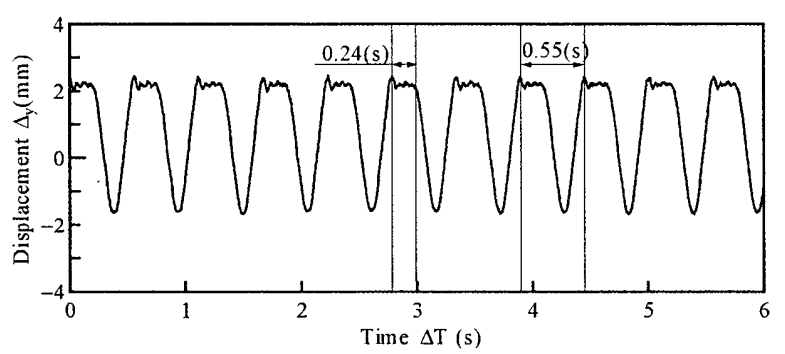

(e) 水中ポンプ回転数 $1440[\mathrm{rpm}]$ （弁閉塞時間 $0.24 \mathrm{~s}$; フロート基本振動数 $1.82 \mathrm{~Hz}$ )

Figure.6 空気弁フロートの振動計測結果 
果のためにフロートの空中固有振動 $4.0 \mathrm{~Hz}$ が水中では $2.71 \mathrm{~Hz}$ に低下していること、第 2 に、一弁の閉塞時間が $0.27 \mathrm{sec}$ 持続し ている点である。特に後者の結果は、弁の急閉塞によって発生 した水圧の急上昇すなわち水撃波が $80 \mathrm{~m}$ の空気管内を 1 往復 した時間を代表したものである。この結果から水撃波の伝播速 度が $593 \mathrm{~m} / \mathrm{s}$ と推定でき、空気管内の水撃波の固有振動数が $1.85 \mathrm{~Hz}$ であったことが分かる。

理論的に計算できる水撃波の伝播速度：

$$
a=\frac{\sqrt{K / \rho}}{\sqrt{1+K D /(E s)}}
$$

は、水の体積弾性係数 $\mathrm{K}=0.2 \times 10^{10}\left[\mathrm{~N} / \mathrm{m}^{2}\right]$ 、密度 $\rho=1000\left[\mathrm{~kg} / \mathrm{m}^{3}\right]$ 、 管内径 $\mathrm{D}=80[\mathrm{~mm}]$ 、管の綐弾性係数 $\mathrm{E}=200[\mathrm{GPa}]$ 、管壁厚さ $\mathrm{s}=2[\mathrm{~mm}]$ であるので、 $a=1195 \mathrm{~m} / \mathrm{s}$ となる。実測推定值 $593 \mathrm{~m} / \mathrm{s}$ は理論值の約 50\%になっている。管内面に硬質ではあるが塩 化ビニルライニング加工をしていること、管路に曲がり部分 が多数あること、気泡の残留分もあるなどのために、現実の 水撃波伝播速度がこの程度の值 $593 \mathrm{~m} / \mathrm{s}$ にまで低下したものと 考えられる。

(b)図は水中ポンプ回転数が 822rpm の場合の結果である。(a) 図の場合と全体的な傾向は同じである。減衰振動の固有振動が 少し大きくなって $2.86 \mathrm{~Hz}$ になっている。弁の閉塞時間は $0.30 \mathrm{sec}$ であり、(a)図の場合とほとんど変わっていない。フロ 一トの基本振動数はかなり低い $0.48 \mathrm{~Hz}$ である。

しかし、(c)図に示すように、水中ポンプ回転数が 1050rpm に なると現象が全く変わってくる。弁の閉塞時間には依然として 変化は現れず $0.28 \mathrm{sec}$ であるが、弁が開いてから閉じるまでの 時間が極端に短くなっている。そのため弁の振動数は $1.37 \mathrm{~Hz}$ に上がっている。水撃波の固有振動数に近づいている。

さらに、(d)図に示すように、水中ポンプ回転数が 1095rpm に 上がると、弁の閉塞時間は同じ $0.28 \mathrm{sec}$ であるが、フロートの 基本振動数が $1.49 \mathrm{~Hz}$ になり、さらに水撃波の固有振動数に近 づいている。

さらに、水中ポンプ回転数を $1440 \mathrm{rpm}$ に上げると、(e)図に示 すように、弁の閉塞時間は少し低下して $0.24 \mathrm{~Hz}$ になり、一方 フロートの基本振動数は $1.82 \mathrm{~Hz}$ に上がっている。この状態で はフロートの振動数が水撃波の固有振動数に非常に近い值に なっている。

水中ポンプ回転数を細かく変化させて同様な実験を行った 結果を、弁の閉塞時間 $\Delta \mathrm{T}$ 、水撃波の固有振動数 $\mathrm{f}_{\mathrm{w}}$ 、フロート の基本振動数 $\mathrm{f}_{\mathrm{v}}$ についてまとめたものが図 7 である。図にはフ ロートの水中固有振動数も数は少ないがプロットしている。横 軸の水中ポンプ回転数が大きくなるにしたがって、弁閉塞時間 が徐々に小さくなっている。これは管内圧力が大きくなり、そ れに応じて水撃波の伝播速度が大きくなるためである。これに 応じて空気管内の水撃波固有振動数が徐々に大きくなる。それ に引きずられるようにフロートの自励振動数が大きくなって いる。

\section{6. 結言}

本研究では、主放水管、副ゲート、主ゲート、空気管、空 気弁から構成されるダム利水放水管設備小形モデルを製作し、 空気弁の引起す自励振動問題について再現実験を行った。そ の結果、弁内部のフロートの非常に激しい自励振動を再現す ることができた。自励振動には放水管内に発生する水撃波が 密接に関係していること、その固有振動数に近い周波数で自 励振動が発生することも明らかにすることができた。

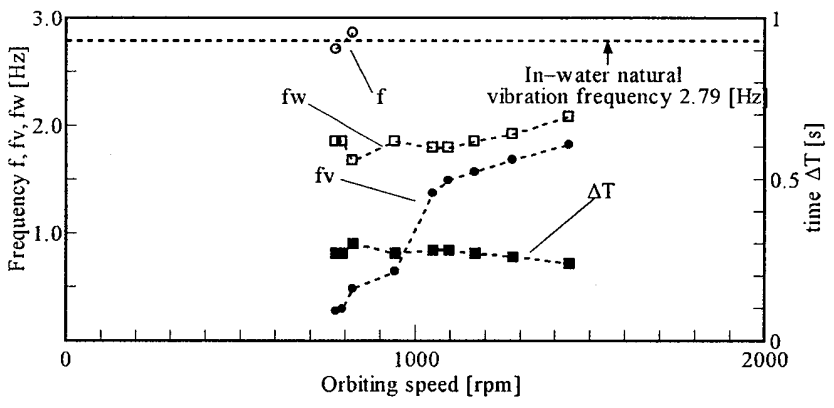

Figure. 7 弁の閉塞時間 $\Delta \mathrm{T}$ とフロートの基本振動数 $\mathrm{f}_{\mathrm{v}}$ および

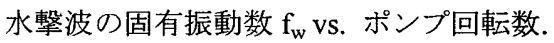

今回の実験では、放水管の長さによって決まる水撃波の固 有振動数が比較的管内圧力が高いときで $1.8 \mathrm{~Hz}$ 、これに対し て、フロートの水中固有振動数が $2.71 〜 2.86 \mathrm{~Hz}$ であり、両者 がある程度離れていた。もし、水撃波固有振動がフロートの水 中固有振動数にもっと近づいていれば、もっと激しい自励振動 が発生していたものと考えられる。

今回の実験では時間的な制約もあって詳細なデ一タ計測が できていない面が多くある。今後、詳細なデー夕計測を進めて いく予定である。さらに、放水管の長さをもっと短くする、あ るいは、フロートの水中固有振動をもつと下げるなどの方法に 上って水撃波固有振動と空気弁の水中固有振動数とを近づけ た状態についても詳細な検討を行っていく予定である。

\section{参考文献}

(1)(独)水資源機構 $\mathrm{H}$ ダム管理所 - (財団法人)水資源機構 : H ダム主放流管用空気弁上下運動対策検討会最終報告書.

(2)中井啓介：修士学位論文「ダム放水管設備における自励振 動実験とそれに起因した空気バルブの振動」2003-3、大阪 電気通信大学大学院.

(3)牧野隼: 卒業論文「ダム放水管設備のダートが引き起こす自 励振動の基本発生メカニズムに関する研究」2005-3、大阪電 気通信大学.

(4)谷野真吾 : 修士学位論文「水理構造物の流体関連振動に関 に関する研究」2007-3、大阪電気通信大学大学院. 